\title{
Obama, Trump and North Korea
}

\author{
Bruce Cumings
}

\section{Introduction}

President Barack Obama's historic "Pivot" to Asia, formally announced in late 2011, would come to have little appreciable effect on US policy towards the Democratic People's Republic of Korea (DPRK), other than a dramatic uptick in Kim Jong-un's nuclear weapons development programme. Obama's "strategic patience" towards Pyongyang failed to halt or slow its development of weapons of mass destruction, but it did manage to initiate greater levels of Sino-US cooperation over sanctioning the regime, the introduction of more US resources and weapons to the region (of which China disapproved), and helped tighten the security relationship between the Republic of South Korea (ROK) and Japan. Frustrations in Washington over North Korea intensified towards the end of Obama's second administration as bipartisan support for a more assertive or aggressive policy grew. Obama therefore set the stage for a more aggressive American stance for his successor to the White House, yet no one anticipated the intensity of the rhetoric which President Donald Trump would employ as he threatened 'fire and fury' and total annihilation on the tiny Asian state. Historic summits with Kim Jong-un in late 2018 and early 2019 brought some hopes of a potential for the denuclearisation of the Korean Peninsula, but familiar underlying patterns in the relationship endured.

\section{North Korea in Obama’s Pacific Century}

President Barack Obama's initial stance towards North Korea can at least partly be inferred from his inaugural address in January 2009. 'To those who cling to power through corruption and deceit and the silencing of dissent,' he asserted, "know that you are on the wrong side of history, but that we will extend a hand if you are willing to unclench your fist.' ${ }^{1}$ The North Koreans proceeded to fire off a 
long-range missile in April 2009, and test an atomic bomb on American Memorial Day in May. On 4 July, they tested seven short and medium range missiles. These provocative actions put North Korea on Obama's back-burner for most of his first term, and he instead reached out to other former enemies or pariah states which he felt might be more receptive to overture, including Cuba, Iran, Burma and even Laos.

One might have thought North Korea would have been a bigger concern because it was the most dangerous actor in the region Obama had quickly come to identify as his foreign policy priority, namely the Asia Pacific. Obama's Pivot promoted a series of defence policy moves which, at the time, appeared to foreshadow the most significant transformation of the United States' global military position since the end of the Cold War and the collapse of the Soviet Union. The shift began with Secretary of State Hillary Clinton's declaration of America's 'Pacific Century'. Clinton announced a shift away from the wars in Iraq and Afghanistan and 'a strategic turn' towards the Asia Pacific, a region now said to be 'the key driver of global politics' where nearly half the world's population lives, and where 'key engines' of the world economy reside. The security of those engines, she noted, 'has long been guaranteed by the US military', and their region would be more important and more central to American interests than any other for the remainder of the century. ${ }^{2}$

Meanwhile, Obama's Defense Secretary Leon Panetta expressed preference that the United States voluntarily relinquish the ability to fight large wars along both the central front in Europe and in East Asia. This "two war" posture had defined Pentagon strategy for the past six decades. He also indicated that the defence triad of air, naval and land forces was outmoded. ${ }^{3}$ The seemingly endless European crisis over national debt in Greece, Portugal and Spain, with the future of the euro and the European Union itself hanging in the balance, added its own punctuation to the apparent eclipse of Europe and the dawn of a new Pacific era. Still, it may just have been that Panetta had run some new ideas up the flagpole to see what would happen; the Pentagon later appeared to retreat from giving up the two-war strategy and the triad. ${ }^{4}$

The Obama administration was the first since the Cold War ended to pay little or no attention to nuclear-armed North Korea. This was perhaps guided by Colin Powell's warning to Pyongyang that 'you can't eat plutonium. You can't eat enriched uranium, and that those who could help feed poverty-stricken North Korea would not do so until it ceased its development of nuclear weapons. ${ }^{5}$ But the White House paid particularly close attention to easing strains both with Tokyo over US bases in Okinawa (which brought down the Hatoyama cabinet in 2010), and with Seoul over changes to the US defence posture in Korea. Indeed, USSouth Korea relations had been at an all-time low from 2002 to 2007, with George W. Bush and President Roh Moo Hyun barely on speaking terms throughout that period. More broadly, along a great crescent from Rangoon to Darwin to Manila 
to Seoul to Tokyo, diplomatic efforts were underway with the permanency of the US Pacific defence posture in mind. That posture, with its political-economic corollary, is now around seventy years old and has provided a remarkably durable regional order for the vast economic exchange taking place in recent decades. A key difference now was the remarkable emergence of China as a leading global actor, and a recognition that the significance of this issue had gone largely unaddressed during the Bush administration.

\section{Obama meets regional historical legacies}

For his East Asia policy, Obama from the beginning relied on battle-tested, triedand-true insiders (that is, inside the Beltway) who typically move in a lockstep, bipartisan fashion - regardless of which president or party happens to be in office - towards their desired policies. Hillary Clinton was the perfect Secretary of State for such people, as a quintessential product of the Beltway herself, beginning with her Watergate investigation days in the early 1970s. And on his arrival to the White House in 2009, Obama found a big problem, a smaller problem, and a clear remedy.

The big problem was the physical rise of China, which needed somehow to be contained, while not disrupting global economic exchange. The remedy was to get Japan and South Korea working together under the umbrella of the American alliance. The smaller problem, however, was that Seoul had been through a fit of "anti-Americanism" as Beltway denizens saw it, under Presidents Kim Dae-jung (1998-2003) and, especially, Roh Moo-hyun (2003-8). Fortune eventually smiled in the form of President Lee Myung-bak (2008-13), a former Hyundai executive who harked back to the days of Korean-American amity when the dictators were in power (1948-87). Even better, they thought, was the subsequent election of Park Geun-hye, a daughter of one such former dictator, who stayed in power until 2017. Also in 2012, however, came Japanese Prime Minister Shinzo Abe yet again, and the best laid Beltway plans went awry.

Abe's grandfather, former Japanese Prime Minister Kishi Nobusuke, was in charge of munitions in Manchukuo when Kim Jong-un's grandfather, Kim Il-sung, was fighting the Japanese in the 1930s. Grandchild Kim and grandchild Abe were thus always likely on a collision course. The arrival of Park Geun-hye stirred the pot, since her father, Park Chung-hee, had been an officer in the Japanese Imperial Army, also in Manchukuo, and had colluded with Kishi in the still-controversial normalisation of Japan-South Korean relations in 1965. Standing behind all this was the United States, which, after momentarily designating Kishi a Class A war criminal and incarcerating him in Sugamo Prison, promoted him as an anti-communist and moderniser. The US Military Government in South Korea (1945-48) guided Manchukuo officer Park through its military academy in 1946, 
and supported him after he led a successful coup of the national government in 1961. The Americans then pushed hard for a normalisation of Japan-South Korea relations, but have never shown much regard for long-standing Korean hatreds and grievances arising from nearly four decades of Japan's colonial rule (1910-45). Instead, from the 1940s to the present, Americans have urged Koreans to unite under the fabled US-Japan alliance.

This and other important elements of twentieth-century history severely constrained President Park, as she sought to manoeuvre between a voting public that suspected she was pro-Japanese, and an Obama administration that wanted her to ally with Abe to help in the containment of China. But to all appearances Park hated Abe; for years she refused to consent to a summit with him in spite of sustained pressure from Washington and Tokyo to do so. Park denounced visits by Abe and his close aides to the Yasukuni Shrine and was particularly vociferous on the issue of Tokyo's continuing unwillingness to deal honestly with the legacy of its wartime sex slavery and the "comfort women" it abused, the vast majority of whom were Korean. So, while Park would talk to President Xi Jinping of China, and vice versa, she would not talk to Abe or Kim Jong-un. Xi would also not talk to Abe or Kim. That nobody at all talked to Kim was no doubt of great personal consternation.

A former Soviet official who had worked in North Korea once told me that you could try to direct, or cajole, or nudge the leadership in Pyongyang to do something which, to a foreigner, looked to be in their best interests. They would smile, seem to nod assent, or might even say yes. Then they would do the opposite, even when it directly contradicted their presumed interests. You could call it stubbornness or solipsism; they didn't care. But this dogged insistence on going their own way is as much a part of North Korea's historic behaviour pattern as it is a palpable obstacle to international cooperation today.

In March 2013, Obama responded to North Korean threats and intransigence with a US $\$ 1$ billion acceleration of the American ballistic missile interceptor programme, adding fourteen new batteries in California and Alaska. (Such anti-missile forces were also recognised as useful against the type of antiquated Intercontinental Ballistic Missiles (ICBMs) held by China.) Later that month, Obama sent B-52 and B-1 Stealth strategic bombers over South Korea to drop dummy bombs. It was a needless and provocative move. In 1951 Washington initiated nuclear blackmail of the North when it launched B-29s on simulated Hiroshima-Nagasaki bombing missions. Operation Hudson Harbor sought to ascertain the feasibility of atomic weapon use on the battlefield, and B-29s were sent over North Korea on practice atomic runs, dropping dummy A-bombs or heavy TNT bombs. ${ }^{6}$ Ever since, nuclear weapons have been part of American war planning against the North. They were not used during the Korean War because the US Air Force was able to raze every city in the North with conventional incendiaries. Few Americans are familiar with this horrific experience, but North Koreans are. It is little wonder, then, that some 
15,000 underground facilities have been dug in the name of national security. In short, however provocative the North appears, the United States is reaping the whirlwind of historic nuclear bullying.

\section{Failed talks and culture wars}

In early 2012 Washington moved to revive local dialogue by tabling a package of proposals aimed at restarting the Six-Party Talks between the United States, the DPRK, South Korea, China, Japan and Russia. The talks had run intermittently from 2003 but collapsed in 2009 when the DPRK withdrew in protest of UN sanctions imposed by its April 2009 missile tests. The result was the so-called Leap Day Deal, signed in Pyongyang on 29 February 2012. The Deal would see food aid to North Korea in return for a moratorium on testing nuclear weapons or launching long-range missiles. Pyongyang claimed the agreement did not prevent it from launching satellites, which DPRK forces claimed they were attempting with the launch of a long-range rocket. Washington argued that this violated the agreement, and the Leap Day Deal was quickly rendered void. ${ }^{7}$ The death of Kim Jong-il in December 2012, while the talks were in full swing, disrupted the course of discussion before Kim Jong-un could take his place. The United States, however, treated it as a direct stab in the back, ending any attempts at engagement, while the DPRK claimed it had informed the Americans of the coming launch.

While Obama had been quickly greeted with North Korean bomb and missile tests on entry into office, it was also China's turn to consider the knife sticking out of its own back. PRC forces saved North Korea from oblivion when they intervened in the Korean War in 1950 and has, certainly since the end of the Cold War, represented its closest (arguably only) ally. After the North's third nuclear test in February 2013, however, Beijing was openly critical of Pyongyang's actions and argued that they threatened world peace. ${ }^{8}$ Relations between the two countries became unprecedentedly cold. Xi met several times with South Korean President Park, and on the eve of Xi's visit to Seoul in July 2014, Pyongyang showed its pique by launching several short and medium range missiles.

As 2014 came to an end, an unpredictable set of events involving North Korea mingled tragedy and farce in ways that simultaneously reflected both the absurdity and the perils of that country's place and significance in the world. Hackers who may or may not have been North Korean unloaded huge tranches of data from Sony Pictures in protest of the film, The Interview, which climaxed with a gruesome assassination of Kim Jong-un. The hackers then threatened to attack any theatres that would show the film. Large theatre chains opted not to screen it, and Sony pulled the movie before later relenting to pressure and releasing it.

Had the film depicted the decapitation of Barack Obama, Xi Jinping, or many other recognised foreign leaders, its makers would have been castigated. But it was 
aimed at North Korea, a country with no real friends. As such, the American media can say and do anything it wants, and very few protest. Most interesting then, and most typical of any number of crises over North Korea, is that Pyongyang made wild charges - in this case that the US government backed The Interview - and media commentators mocked Pyongyang's paranoia. Further examination, however, then reveals that a kernel of truth lay at the bottom of the North Korean claims; the American media was not only wrong, but as usual failed to do any investigative reporting into the matter.

During a US Strategic Command symposium in August 2014, Major General John MacDonald, formerly of US Forces Command in Korea, advocated the assassination of North Korean leaders. The video of this symposium was circulated by the Strategic Command, in the knowledge that officials in Pyongyang watch this periodic symposium every time it airs. ${ }^{9}$ Furthermore, Sony emails show that company executives consulted with the State Department and CIA about any backlash that might occur from releasing the film; Bruce Bennett, a consultant with the US government, told Sony in June 2014 that the only way to get rid of the North Korean regime was to assassinate its leader. Bennett also told Sony that the imagery of Kim's gruesome murder in The Interview should be kept to be leaked into North Korea as a samizdat DVD to help destabilise the regime. ${ }^{10}$ In the midst of this episode, Richard Haass, President of the Council on Foreign Relations, published an editorial in the Wall Street Journal which advocated regime change, or as he put it, 'ending North Korea's existence as an independent entity and reunifying the Korean Peninsula." ${ }^{11}$

If a North Korean leader, including Kim Jong-un, were to be assassinated by American forces, it is very possible that the truce on the Korean Peninsula would break and open war would resume. It seems it did not occur to Americans working for Sony that Pyongyang would naturally see the film not just as an American product but one manufactured in Japan, the North's colonial enemy and bête noire for seventy years.

\section{Chinese frustrations and American failure}

China's reliance on North Korea as a problematic but useful "buffer" between itself and the South necessitates its uneasy alliance with Pyongyang; no Chinese leader wants the ROK, with 28,000 American troops in its territory, to control the Yalu River border. Indeed, Obama's strategy throughout his time in office of seeking to persuade the leaderships of both South Korea and Japan to leave behind their nations' historical grievances and unite in reinvigorating the United States' regional influence by proxy was not lost on Beijing. To this end, in late 2015, Beijing sent Politburo Standing Committee member Liu Yunshan to Pyongyang on the seventieth anniversary of the founding of its Worker's Party. Liu became 
the highest-ranking visitor from the PRC in several years. Some analysts surmised that the deal to be struck on the visit was a pledge from the North not to test any more A-bombs or long-range missiles. Liu reportedly asked Kim to stop testing atomic weapons, but more quickly followed. ${ }^{12}$ In February 2016 Beijing sent top North Korea specialist Wu Dawei to Pyongyang to request a halt to tests of longrange missiles. Wu was barely back home before reports of more tests. ${ }^{13}$

The key irritant in Sino-North Korean relations, including throughout the Obama era, has been that with every A-bomb or missile test Washington ramps up its deterrence efforts in Northeast Asia. US carrier task forces have been rerouted to the Yellow Sea; B-1 and B-52 bombers have been sent to the Korean theatre; and ever more anti-ballistic missile batteries, which China sees as a threat to its older missiles including its antiquated ICBMs, have been sold to allies or dispatched. On the surface, this would appear to be a problem for Pyongyang. Most goods available in its markets are made in China and it earns significant amounts from Chinese firms exploiting its natural resources. However in recent years China has also become more accepting of UN sanctions on the North. This invites a uniform view of the Chinese Communist Party's attitudes towards North Korea when in fact the leadership, and the general public, are in fact quite split. Many hardliners in the Chinese military and the CCP empathise with the North. This often coexists with a mistrust or even acrimony for the United States. Xi Jinping is the first Chinese leader to so openly denounce Pyongyang's provocations; his predecessor, $\mathrm{Hu}$ Jintao, lauded the North's closed political system for its ability to repel subversive Western ideas and practices. ${ }^{14}$

The general view of North Korea across the American political spectrum, Democrat and Republican, meanwhile, has long been that it is an evil regime. Perhaps it is this which inhibits serious US investigative reporting and debate on North Korea. That deficiency, in turn, means that even the highest US officials often know next to nothing about the country. For instance, former Defense Secretary Leon Panetta writes about the Korean War as if he just discovered it, with a boilerplate description of his visit to Panmunjom that could have been written forty years ago. In passing, Panetta trots out a venerable shibboleth from the Orientalist playbook; he eyeballs an 'inscrutable' North Korean soldier across the DMZ, 'just as inscrutable as the regime behind him. ' [I]t is an exasperatingly difficult culture to observe and understand ..., he writes, '... our insights into the regime were few and shallow ... Still, the regime was infuriatingly hard to penetrate.' Yet he is curiously matter-of-fact in saying that, '[i]f North Korea moved across the border', the United States would command the ROK's military and would 'defend South Korea - including by the use of nuclear weapons, if necessary.' ${ }^{15}$

This is a naive but telling passage. A small Asian country is seen as 'inscrutable', and that is infuriating; power needs to know, so why don't they let us know everything we want to know? Following the launch of the North Korean rocket which signalled the end of the Leap Day Deal, Panetta asserted that the United States 
was prepared for 'any contingency' with regard to North Korea. 'We're within an inch of war almost every day in that part of the world', he said, 'and we just have to be very careful about what we say and what we do. ${ }^{16}$ For American presidents and their officials to contemplate unprovoked attacks against the North is both a stunning example of American arrogance and an astonishing admission of failure, the roots of which extend for perhaps seven decades. This has been a failure to remove the risk of war in Korea, and to make peace with an adversary determined to wait the United States out forever, if that is what it takes.

In 2015, an Obama Doctrine seemed finally to have emerged. 'We will engage, but we preserve all our capabilities', he claimed. Engagement while 'meeting core strategic needs', he said, would serve American interests in new relations with Iran, Burma and Cuba. ${ }^{17}$ The Obama administration, then, was to end with new relationships with nearly every former pariah state. Yet the most important one, North Korea, remained out in the diplomatic cold. (As of early 2019, battletorn Syria occupies its own unfortunate political space, clinging precariously to statehood.) Despite, or perhaps because of, this, North Korea arguably remains far more dangerous than the others, not least because of its precisely unquantifiable nuclear arsenal. At the very least, however, it has on occasions shown itself to be receptive to US presidential diplomacy towards its nuclear and missile programmes. This, indeed, has always been a crucial element of its design.

\section{Trump and the return of US unilateralism}

The election of Donald Trump in November 2016 brought into the White House a person with no foreign policy experience, riding a swell of opposition to free trade, internationalism, and the rules of the international game since 1945. Trump has shown he is an American nationalist of the first order. His appeals to racism and anti-immigrant sentiment, and opposition to free trade and a determination to set tariffs on exporters to the American market, put him in line with prominent isolationists of the 1930s. ${ }^{18}$ During his campaign, Trump complained that 'we defend everybody', and that 'we will not be ripped off anymore'. He then threatened to withdraw American protection from Japan and South Korea, including the nuclear umbrella, asking why they don't defend themselves against North Korean nuclear weapons and missiles. ${ }^{19}$ His naïveties had already been illustrated in 2016 when, as a presidential candidate, he announced that he would be willing to meet with Kim Jong-un without preconditions or concessions, a desire he reiterated a year later as president. ${ }^{20}$

Notably, Trump said he wanted to renegotiate security pacts with Japan and South Korea, among others, unless they start 'paying their way'. Asked by the New York Times if he was isolationist, he denied this but asserted that he was 'America First. I like the expression'. When asked to point back into history to the 
peak of American power, he identified the era of Theodore Roosevelt, and said that two of his favourite Americans were generals Douglas MacArthur and George S Patton. ${ }^{21}$

The cunning of history is such that its emissaries sometimes arrive in strange form. Donald Trump is no exception. Andrew Bacevich's 2005 critique of American power coincided with my own sense that a fundamental rethinking of America's relationship to the world is required..$^{22}$ Bacevich outlines a number of principles, the first of which is to 'heed the intentions of the founders'. Nothing in the Constitution, he observes, 'commits or even encourages the United States to employ military power to save the rest of humankind or remake the world in its own image'. He argues for Congress to reassert its constitutional obligations in foreign affairs: 'to view force as a last resort'; to limit American dependence on foreign resources; to organise US forces for national defence rather than power projection; and to reconcile the professional military with the realities of American society. These principles, which I share, call for a full rethinking of the many American bases and garrisons abroad, and truly significant reductions in defence spending. This would only bring the United States into consonance with what its advanced industrial allies spend on military power projection. ${ }^{23}$ As of early 2019, it does not seem that Donald Trump is serious about bringing the troops home. At the same time, however, he is the only president since 1945 to repeatedly suggest his intentions to do so.

In February 2017 Trump was having dinner at Mar-a-Lago with Japanese Prime Minister Shinzo Abe when it emerged that under Kim Jong-un's direction, North Korea had tested a new, solid-fuel missile fired from a mobile (and therefore difficult to detect) launcher. The president discussed the issue on his own telephone in front of the various people sitting with him. ${ }^{24}$ This missile was a pointed nod to history that no American media outlet grasped; as already noted, Shinzo Abe is the grandson of former Japanese Prime Minister Kishi Nobusuke, a political leader in 1930s Manchuria. Kim Jong-un's grandfather, Kim Il-sung, spent a decade fighting the Japanese at the same time in the same place.

The American media appear to live in an eternal present, with each new crisis treated as sui generis. Likewise, every episode with the DPRK during the first two years of the Trump administration seemed to be accompanied by the refrain that the country has a history of violating one agreement after another. In fact, Bill Clinton struck a deal which saw Pyongyang cease plutonium production between 1994 and 2002. In October 2000 Washington and Pyongyang reaffirmed their commitment to that Agreed Framework, and another was signed in the White House with General Jo Myong-rok stating that neither country would bear 'hostile intent' towards the other. ${ }^{25}$ The Bush administration ignored both agreements and under John Bolton's influence as Under Secretary of State for Arms Control and International Security Affairs, later National Security Advisor under Trump, it set out to destroy the 1994 Framework. The simple fact is that Pyongyang would 
have no nuclear weapons today if Clinton's agreements had been maintained by Washington.

\section{Breakthroughs and false hope (?)}

North Korean technological advancements of weaponry, evident throughout Obama's time in office, continued throughout the first two years of the Trump administration. Indeed, 2017 saw a flurry of long-range missile tests from North Korea, demonstrating its ability to strike the mainland United States. It also saw the tragic death of Otto Warmbier, an American citizen held captive in Pyongyang after being accused of stealing a propaganda sign while on a visit to the country. UN sanctions followed, and in August 2017 Trump asserted that North Korea would be met with 'fire and fury like the world has never seen' if it continued to threaten the United States. ${ }^{26}$ In his September 2017 address to the United Nations, he threatened 'to totally destroy' North Korea. ${ }^{27}$ Kim Jong-un called Trump a 'dotard' and 'deranged'; Trump nicknamed Kim the 'little rocket man'. ${ }^{28}$ US-North Korea relations had become dangerously unstable as two cantankerous and highly egotistical leaders clashed.

In November 2017 Trump declared the era of "strategic patience" over. ${ }^{29}$ Trump's early approach to North Korea, then, in almost every respect, could hardly have presented a more striking contrast to that of Obama. Around the same time, the centrist Council on Foreign Relations issued a report stating that 'more assertive military and political actions' towards the DPRK should be considered, 'including those that directly threaten the existence of the regime. ${ }^{30}$ Secretary of State Rex Tillerson had warned of pre-emptive action during his trip in March to East Asia, ${ }^{31}$ and a former Obama administration official, Anthony Blinken, wrote that a priority for the Trump administration should be to work with China and South Korea to 'secure the North's nuclear arsenal' in the event of regime change. ${ }^{32}$

The dawn of 2018 saw Kim Jong-un deliver an unusually conciliatory New Year's address. South Korean President Moon Jae-in quickly invited a North Korean team to the PyeongChang Winter Olympic Games in February, in which the delegations competed under a symbolically powerful unified flag. Kim's sister, Kim Yo-jong, and Kim Yong-chol, a former intelligence chief, impressed the crowds with their quiet dignity and apparent rapport with Moon. A concomitant shift in rhetoric followed between Trump and Kim, for which Trump claimed responsibility. Kim made his first foreign trip as leader to Beijing for talks with Xi Jinping in March, before then-CIA Director (and nominated new Secretary of State) Mike Pompeo travelled to Pyongyang in April. In June 2018 Trump and Kim met at a historic summit in Singapore; Trump became the first sitting US president to meet a North Korean leader. From the summit came an eye-catching but vague commitment to denuclearisation, and an equally vague commitment to a new peace regime on 
the Korean Peninsula. ${ }^{33}$ The summit also drew criticism from those who noted that it handed Kim Jong-un a valuable domestic propaganda opportunity he had always craved. Regional governments nonetheless expressed hopes that USDPRK tensions, which had so recently all-but boiled over, had abated, and that a path towards denuclearisation of the Korean Peninsula and geopolitical stability in Northeast Asia might lie ahead.

Hopes of genuine sea change come rarely around North Korea and so the expectations of experienced observers were understandably cautious. Credible reports nevertheless emerged that the Kim regime was dismantling missile testing and production facilities and that anti-US propaganda materials were being removed from North Korean streets. The DPRK's large, annual "anti-US imperialism" rally was called off in the summer of 2018. Trump, meanwhile, proclaimed that he and Kim Jong-un 'fell in love' in Singapore and joint military exercises with the South were postponed to avoid antagonising the North. ${ }^{34}$ Yet, by December Pyongyang made it clear that they would not relinquish their nuclear capabilities until the United States removed its own from the South and the wider region, raising questions about exactly what had been agreed in Singapore. ${ }^{35}$ Investigation also indicated that the DPRK maintained numerous active, undeclared missile sites. ${ }^{36}$ A second summit between Trump and Kim in February 2019 ended without major agreement. An announcement in March that annual US-South Korea military exercises were being permanently cancelled to aid denuclearisation efforts brought criticism that the tail of Pyongyang was wagging the dog of the United States and its allies, by succeeding in eroding the regional American security presence. ${ }^{37}$ In truth, North Korea has to varying extents been steering and manipulating the security environment of East Asia for decades, not least since the end of the Cold War and the collapse of its main communist support structures. In early 2019 it continues to do so, despite the unorthodox theatrics initiated by Trump.

\section{Conclusion}

Across President Obama's two terms in office, his "strategic patience" towards the DPRK got very little from Pyongyang besides an ever-growing reliability of its A-bombs and missiles. Still, there was little real choice but to talk to the North Koreans, by broadly adopting the logic of Siegfried Hecker, former Director of the Los Alamos National Laboratory, who argued to sustain a message of "three no's” towards North Korea: 'No more nukes, No better nukes, No proliferation'. In return, Pyongyang would be able to keep its existing stockpiles but expand them no further, in exchange for concessions. ${ }^{38}$ Over time Beijing became more active in backing UN sanctions against Pyongyang, though it is an open question as to how much influence Obama exerted on that shift. His Pivot to the region brought more 
diplomatic and security resources to the region, including the THAAD missile system in Hawaii and Guam, and eventually, in South Korea. It also encouraged closer security ties between Seoul and Tokyo.

To this extent, Obama left a legacy of sorts in Washington's relations with Pyongyang; by embracing regional multilateralism over unilateralism and rejecting the rhetoric of an "Axis of Evil" - both key features of the Bush administration's regional strategy - and even to some extent by simply neglecting North Korea altogether, Obama succeeded in defusing some of the tensions brought by his predecessor's obsession with terror and "rogue states" like North Korea, especially in his first term. The arrival to power of Kim Jong-un in 2012 brought a renewed acceleration of the DPRK's nuclear and long-range missile capabilities. This, combined with Obama's focus on securing a nuclear deal with Iran (achieved in 2015), emboldened Pyongyang. In many ways then the Obama administration kicked the North Korean can down the road. Its aim was to seek closer diplomatic and security agreements with its neighbours, particularly South Korea and Japan, but also China, to reinforce Washington's regional authority and exert indirect influence over Pyongyang. This effort towards "outsourcing" security was a key feature of the Pivot in broad terms. China's increased willingness to support US-led sanctions on North Korea also reflects well on Obama, though this also contributed to frustrations in Pyongyang and its relationship with Washington progressively worsened.

From 2017, Donald Trump took the US-North Korea relationship on a diplomatic rollercoaster up until the time of writing in early 2019. Trump's open admiration for historical figures including Theodore Roosevelt and Douglas MacArthur, as well as his notoriously fragile temperament, help explain his natural recourse to military solutions and markedly aggressive rhetoric towards Pyongyang, especially in his first twelve months in the White House. Trump's fondness for disparaging the record of his presidential predecessor led him to declare an end to Obama's "strategic patience", though this was likely as much for show as a sign of personal conviction. More broadly, by immediately questioning the benefits Washington derives from its alliances and military presence in Asia, and arguing that its closest regional allies needed to "do more", Trump began to erode Obama's two-term project of local trust and consensus-building. Neither president, sadly, has taken at all seriously the plight of the millions of innocent North Koreans starving and/or locked away in prison camps. These are the timeless victims of both a murderous regime and a lack of American leadership on human rights.

The regime in Pyongyang senses an opportunity in Donald Trump; by carefully playing to his curious admiration for authoritarian "strongmen" and questionable commitment to regional security, Kim Jong-un has become closer to an American president than either his father or grandfather managed, yet both Trump and Kim are highly unpredictable characters. The problem for North Korea is that its image 
among the American public and many of their policy makers (Trump's personal up-down relations with Kim notwithstanding) is so negatively charged, and one of an almost inhuman authoritarian machine the world would be better without. Leon Panetta's observation that the two sides so often come 'within an inch of war' is therefore a result of American politics as well as those of the DPRK. Ultimately, long-term solutions to the challenges posed by North Korea must have the support and participation of neighbouring South Korea, China and Japan. Trump may see America First, but to cement a positive legacy of his own on the peninsula he would need to reach out to those he has already criticised for not contributing enough.

\section{Notes}

1 White House, 'President Barack Obama's Inaugural Address' (21 January 2009), https://obamawhitehouse.archives.gov/blog/2009/01/21/president-barack-obamasinaugural-address, accessed 10 March 2019.

2 H. Clinton, 'America's Pacific Century', Foreign Policy (11 October 2011), http:// foreignpolicy.com/2011/10/11/americas-pacific-century/, accessed 6 March 2019.

3 P. Goodspeed, 'Obama Looks to Counter China’s Influence with Australian Naval Base', National Post (15 November 2011), https://nationalpost.com/opinion/petergoodspeed-u-s-looks-to-assert-itself-in-pacific-region-with-australian-naval-base, accessed 10 March 2019; E. Bumiller and T. Shanker, 'Panetta to Offer Strategy for Cutting Military Budget', New York Times (2 January 2012), www.nytimes.com/ 2012/01/03/us/pentagon-to-present-vision-of-reduced-military.html, accessed 10 March 2019.

4 M. Memmott, 'Pentagon Says Two War Strategy Not Likely to be Scrapped', NPR (5 January 2012), www.npr.org/sections/thetwo-way/2012/01/05/144722456/ pentagon-says-two-war-strategy-not-likely-to-be-scrapped, accessed 10 March 2019.

5 See S. Snyder, 'US-North Korean negotiating behaviour and the Six Party Talks', in S. Joo and T. Kwak (eds.), North Korea's Second Nuclear Crisis and Northeast Asia Security (Aldershot: Ashgate), p. 158.

6 Documents on this project discovered by the author and discussed in B. Cumings, The Origins of the Korean War, 2nd edition (Princeton, NJ: Princeton University Press, 1990).

7 See A. Panda, 'A Great Leap to Nowhere: Remembering the US-North Korea "Leap Day” Deal, The Diplomat (29 February 2016), https://thediplomat.com/2016/02/agreat-leap-to-nowhere-remembering-the-us-north-korea-leap-day-deal/, accessed 12 March 2019.

8 T. Branigan, 'China's Patience with North Korea Wears Thin After Latest Nuclear Test', Guardian (12 February 2013), www.theguardian.com/world/2013/feb/12/ china-north-korea-nuclear-test, accessed 11 March 2019. 
9 P. Hayes, 'Strategic Negligence and the Sony Sideshow', NAPSNet Policy Forum (22 December 2014), https://nautilus.org/napsnet/napsnet-policy-forum/strategicnegligence-and-the-sony-sideshow/, accessed 10 March 2019.

10 Ibid.

11 R. N. Haas, 'Time to End the North Korean Threat', Wall Street Journal (23 December 2014), www.wsj.com/articles/richard-haass-time-to-end-thenorth-korean-threat-for-good-1419376266, accessed 10 March 2019.

12 J. C. Hernandez, 'Hydrogen Bomb Claim Strains North's Bonds with Beijing', New York Times (7 January 2016), www.nytimes.com/2016/01/07/world/asia/ north-korea-china-hydrogen-test.html, accessed 10 March 2019.

13 BBC, 'North Korea Fires Long Range Rocket Despite Warning' (7 February 2016), www.bbc.co.uk/news/world-asia-35515207, accessed 12 March 2019.

14 H. McDonald, 'Mutual Interest Binds China to North Korea', Sydney Morning Herald (16 December 2006), www.smh.com.au/world/mutual-interest-bindschina-to-north-korea-20061216-gdp2cr.html, accessed 10 March 2019.

15 L. Panetta with J. Newton, Worthy Fights: A Memoir of Leadership in War and Peace (New York: Penguin, 2014), pp. 274-6.

16 CNN, 'Panetta: We're Within an Inch of War Almost Every Day' (19 April 2012), https://edition.cnn.com/2012/04/19/politics/pol-clinton-panetta-interview/index. html, accessed 10 March 2019.

17 T. L. Friedman, 'The Obama Doctrine and Iran', New York Times (6 April 2015), www.nytimes.com/2015/04/06/opinion/thomas-friedman-the-obama-doctrineand-iran-interview.html, accessed 10 March 2019.

18 N. Cohn, 'Trump's Secret Weapon: Blue-State Voters', New York Times (27 March 2016), www.nytimes.com/2016/03/27/upshot/trumps-secret-weapon-blue-statevoters.html, accessed 10 March 2019.

19 D. Sanger and M. Haberman, 'In Donald Trump's Worldview, America Comes First, and Everybody Else Pays', New York Times (27 March 2016), www.nytimes. com/2016/03/27/us/politics/donald-trump-foreign-policy.html, accessed 10 March 2019.

20 BBC, 'Donald Trump: I Would be Honoured to Meet Kim Jong-un' (1 May 2017), www.bbc.co.uk/news/world-asia-39773337, accessed 11 March 2019.

21 Ibid.

22 A. Bacevich, The New American Militarism: How Americans Are Seduced by War (New York: Basic Books, 2005).

23 Ibid., pp. 208-21.

24 Y. Alcindor, J. Weisman and A. Stevenson, 'Scenes From Mar-a-Lago as Trump and Abe Get News About North Korea', New York Times (13 February 2017), www. nytimes.com/2017/02/13/us/politics/donald-trump-administration.html, accessed 10 March 2019.

25 US Department of State, 'US-DPRK Joint Communique' (12 October 2000), https://1997-2001.state.gov/regions/eap/001012_usdprk_jointcom.html, accessed 13 March 2019. 
26 J. Pramuk, 'Trump Warns North Korea Threats "Will Be Met with Fire and Fury", CNBC (8 August 2017), www.cnbc.com/2017/08/08/trump-warns-north-koreathreats-will-be-met-with-fire-and-fury.html, accessed 12 March 2019.

27 White House, 'Remarks by President Trump to 72nd Session of the United Nations General Assembly' (19 September 2019), www.whitehouse.gov/briefingsstatements/remarks-president-trump-72nd-session-united-nations-generalassembly/, accessed 11 March 2019.

28 M. Stevens, 'Trump and Kim Jong-un, and the Names They've Called Each Other', New York Times (9 March 2018), www.nytimes.com/2018/03/09/world/asia/ trump-kim-jong-un.html, accessed 14 March 2019.

29 White House, 'Remarks by President Trump and Prime Minister Abe of Japan in Joint Press Conference' (6 November 2017), www.whitehouse.gov/briefingsstatements/remarks-president-trump-prime-minister-abe-japan-joint-pressconference-tokyo-japan/, accessed 11 March 2019.

30 Council on Foreign Relations, 'A Sharper Choice on North Korea: Engaging China for a Stable Northeast Asia, Independent Task Force Report no. 74 (3 October 2016), https://cfrd8-files.cfr.org/sites/default/files/pdf/2016/09/TFR74_North\%20 Korea.pdf, accessed 10 March 2019.

31 M. Fisher, 'The Risks of The Interpreter', New York Times (19 March 2017), A-10.

32 A. Blinken, 'The Best Model for a Nuclear Deal with North Korea? Iran', New York Times (11 June 2018), www.nytimes.com/2018/06/11/opinion/trump-north-koreairan-nuclear-deal.html, accessed 12 March 2019.

33 White House, 'Joint Statement of President Donald J. Trump of the United States of America and Chairman Kim Jong Un of the Democratic People's Republic of Korea at the Singapore Summit' (12 June 2018), accessed 13 March 2019.

34 J. Bykowicz and F. Fassihi, 'Trump Says he and Kim Jong-un "Fell in Love", Wall Street Journal (30 September 2018), www.wsj.com/articles/trump-says-he-andkim-jong-un-fell-in-love-1538336604, accessed 12 March 2019.

35 Guardian, 'North Korea Says it Will Not Denuclearize unless US Removes Threat' (20 December 2019), www.theguardian.com/world/2018/dec/20/north-korea-uskim-jong-un-trump-denuclearize-nuclear-threat, accessed 12 March 2019.

36 Joseph Bermudez, Victor Cha and Lisa Collins, 'Undeclared North Korea: The Sino-ri Missile Operating Base and Strategic Force Facilities' (21 January 2019), https://beyondparallel.csis.org/undeclared-north-korea-the-sino-ri-missileoperating-base-and-strategic-force-facilities/, accessed 23 October 2019.

37 Al Jazeera, 'US, South Korea to End Key Joint Military Exercises' (3 March 2019), www.aljazeera.com/news/2019/03/south-korea-key-joint-military-exercises190303055241782.html, accessed 13 March 2019.

38 S. Hecker quoted in A. Lankov, The Real North Korea: Life and Politics in the Failed Stalinist Utopia (Oxford: Oxford University Press, 2013), p. 280. 